\title{
The sad story of a family with xeroderma pigmentosum
}

\author{
Jack Cohen BSc BA MD CM \\ Jewish General and St Mary's Hospitals, Montreal, Quebec
}

\section{J Cohen. The sad story of a family with xeroderma pigmentosum. Can J Plast Surg 2000;8(5):187-188.}

A family of xeroderma pigmentosum patients, three of whom died of internal malignancies and the fourth of a possible radiation-induced melanoma, is described.

Key Words: Cutaneous malignancy; Lesion; Ocular malignancy; Xeroderma pigmentosum

\section{La triste histoire d'une famille atteinte de xeroderma pigmentosum}

RÉSUMÉ : Voici l'histoire d'une famille de patients atteints de xeroderma pigmentosum, dont trois sont morts de tumeurs internes et le quatrième, d'un mélanome d'origine probablement radique.

$\mathrm{M}$ ost patients who have xeroderma pigmentosum die at an early age because of cutaneous and ocular malignancies that progress to local invasion or metastatic disease. Occasional cases of internal tumours have been reported, but these are rare. In a recent review, only 17 such cases were found, 10 of which were in the tongue or oral cavity (1).

When I first started to practise in 1967, I would occasionally see members of a family with xeroderma pigmentosum in our plastic surgery clinic. Within a few years, I 'inherited' the family and followed each of them until their deaths. The family was an unusual case because of their longevity. One son survived into his early 30 s and another son and daughter survived into their $40 \mathrm{~s}$. Their case was also unusual because three of the four affected siblings died from internal tumours, not from their skin carcinomas, while the fourth sibling may have died of a radiation-induced malignancy.

There were five siblings in the family. The eldest daughter never showed any evidence of the disease. The other four children were born between 1951 and 1955; they began to show the usual signs of the condition as young children, and treatment patterns were established. They were followed at the dermatology clinic of the hospital. Small or suspicious le- sions were treated by cautery and/or curettage and later by 5 -fluorouracil cream. Lesions that required resection were referred to the plastic surgery clinic. Small lesions were resected on an outpatient basis, while large lesions, or those needing more complex closure or reconstruction required admission to hospital.

The eldest daughter, who was free of the disease, started working at my second hospital as a nursing assistant shortly after I was accepted on staff in 1970. Although it was mainly the parents who brought the children in for their various appointments, I kept the nursing assistant appraised of the condition of her siblings because most of the surgeries were done at the other hospital.

A daughter, born in 1956 (her early record is incomplete because she died 28 years ago), was being followed elsewhere because of a supposed keratoacanthoma of the right cheek. When she was first seen by the plastic surgeon, I was still in training. She had an infected, ulcerated mass of the right cheek and orbit. In 1964, she was admitted with a fever of $40.5^{\circ} \mathrm{C}$, and there was evidence of the loss of the right eye and maxilla. The diagnosis on biopsy was a poorly differentiated squamous cell carcinoma. The tumour was believed

Correspondence: Dr Jack Cohen, Jewish General and St Mary's Hospitals, 5885 Cote des Neiges Road, Suite 600, Montreal, Quebec H3S 2T2. Telephone 514-733-1472, fax 514-733-4857, e-mail jackruth@securenet.net 
to be inoperable. She was given a massive dose of radiation of approximately 8000 rads. Eventually, she sloughed not only the carcinoma, but also the entire orbit, eye, part of the maxilla and zygoma. She was left with a thin layer of radiated skin directly over the dura, and arterial pulsations were visible and palpable.

In 1968, she developed an orocutaneous fistula. I attempted an arm to cheek pedicle flap that failed (this was in the era before modern and more effective flaps). A squamous cell carcinoma of the back was resected a year later.

In March 1971, a rapidly enlarging cheek mass was biopsied and at first biopsy revealed a probable low grade fibrosarcoma, but with a more adequate piece of tissue for biopsy, a probable amelanotic malignant melanoma was revealed. Again, in the era before present day flaps, the lesion was believed to be inoperable. Several attempts were made to debulk the lesion with cryosurgery, but it grew rapidly and the patient died shortly thereafter.

The eldest son was born in 1951. His first contact with the plastic surgery department was in 1966 with the removal of four lesions of the face and neck, three of which were mixed basosquamous cell carcinomas and the fourth an ulcerated basal carcinoma. From that time until 1984, multiple lesions were removed either on an outpatient basis or in hospital. Of the 30 admissions to hospital, 24 were for the treatment of his skin cancers. Not including the small lesions treated by the dermatology department, he had 13 squamous cell carcinomas, 12 basal cell carcinomas, six mixed basosquamous carcinomas, five keratoacanthomas and one malignant pigmented tumour. In 1982, a wide resection of a squamous cell carcinoma of the nose and upper lip was done. It recurred approximately one year later, necessitating an en-bloc resection of part of the nose, upper lip, maxillary arch and anterior hard palate. In 1984, while waiting for an adequate time to elapse before attempting reconstruction, urinary symptoms were investigated and the patient was found to have a superficial papillary transitional cell carcinoma of grade 2 or 3 . Shortly thereafter, he was admitted to hospital with back pain and increasing abdominal girth. Exploration revealed a large, inoperable retroperitoneal tumour that was diagnosed as an epitheloid leiomyosarcoma. The patient died of renal failure four days after the operation. During the last few years of his life, he had completed an undergraduate degree at McGill University and he was a few months away from finishing his $\mathrm{PhD}$ thesis in religious studies at the University of Ottawa when he died.

In 1990, the mother died and the eldest daughter was left to care for her two remaining siblings and her father. At that time, she was working at the hospital as a secretary.

The second son, born in 1952, was first seen by the plastic surgery department in 1964, when carcinomas were removed from his lower lip, chin and right temple. There were four ul- cerated basal cell carcinomas and one squamous cell carcinoma. In November 1964, several other carcinomas of the face were removed, including one basosquamous carcinoma, one pigmented malignant tumour and one mixed basosquamous carcinoma. Nine years later, a keratoacanthoma lesion was resected from his lower left lid and one year later, an atypical fibroxanthoma of the left arm was resected. Nineteen years later, tumours started to develop rapidly. Between 1993 and 1997, 19 tumours were resected in batches, including squamous cell carcinomas, basal cell carcinomas, malignant melanomas and keratoacanthomas.

In 1994, he had a craniotomy for what was diagnosed on biopsy as an ependymoma of the brain, which was inoperable. He underwent radiotherapy and three ventricular shunts. Toward the end, he was admitted to the ward where his sister worked. He was stuporous, but his sister said that feeding was painful because of the ulcer on his lower lip. I did a modest resection under local anaesthesia for symptomatic relief. He died a few days later. The lip lesion was diagnosed as a highly aggressive malignant tumour, suggestive of a sarcoma, possibly angiosarcoma.

A daughter, born in 1954, had the mildest form of the skin disease of the affected siblings. Between 1970 and 1983, I removed only three keratoacanthomas of the face and ear. The first true malignancies were removed in 1986, when she was 31.5 years of age. They were squamous cell carcinomas of the upper lip and left cheek. In 1990, much of the lower lip was removed for multifocal superficial invasive squamous cell carcinoma. A recurrence or new lesion was resected three years later. In spite of reconstruction, she was left with a smaller oral commisure.

In 1995, a pelvic mass was discovered. She had a radical resection of the right ovary, a hysterectomy, resection of involved omentum and a pelvic exenteration. The pathology was a poorly differentiated ovarian carcinoma and a prominent small cell component, metastatic to the cervix, uterus and omentum. There was also an endometrial carcinoma with a predominant squamous cell component. She had several courses of chemotherapy but died in February 1996. She had received her MA and was an active teacher until a short period before she died.

The eldest daughter still works at the hospital. She suffered burnout after the illnesses and deaths of her last two siblings. Because of visual problems and their appearance, the boys especially could not have led a normal life. The father recently died of cardiac problems, and the eldest daughter is left only with her memories.

\section{REFERENCES}

1. Kraemer KH. Environmental Dermatoses. In: Demis DJ. Clinical Dermatology. Philadelphia: Lippincott Williams and Wilkins, 1999:19-20. 